\title{
TWO DRESSEL 20 STAMPS FOM PIDDINGTON VILLA, NORTHAMPTON, U.K.
}

Mr. Roy Friendship Taylor submitted to the author a cast of the stamp no 2 and the actual handle which bore $\operatorname{stamp~}^{\circ} 1$ :

1. III ENNI IVL (palme). Unpublished stamp (cf. CIL XV,2,2819,f, Callender 581, Remesal 86, Ponsich 2,43,74), found at the Piddington Villa (BB-CC 23-25 L6 HH Pid. H/F 90); 2.11 x 0.6 Roman inches. Produced at Huertas de Nicasio, and dated at Rome (AD 160) and Augst (AD 70120 ). The reading is III <trium> ENNI(orum) IVL(iorum).

2. SP AE. Unpublished stamp (cf. HISPSAENI, CIL XV,2, 2914, Callender 1550h, Ponsich $2,43,79$, Remesal 131), found at the same site (X/ 20 F567, cellar 2, L\&, room 39, Pid H/F 91); 1.10 x 0.6 Roman inches. Produced at the same pottery and dated at Avenches (AD 50-100). The reading is $<\mathrm{HI}>\mathrm{SP}(\mathrm{ani})<\mathrm{S}>\mathrm{AE}(\mathrm{ni})$ or Saenianensis figlinae.
Both stamps come from the same pottery, Huertas del Río, on the right bank of the Baetis or Guadalquivir Valley, a site probably linked to the ancient Roman town Axati, nowadays Lora del Río, at the Conuentus Hispalensis. The pottery was known as saenianenses figlinae since the AD 60s, and Caius Ennius Hispanus, as well as Hispanus Saen( ) are also dated into the first century AD. The three Ennii Iulii, using the same pottery, are dated in the Antonine Period and we could suppose that these Ennii are related to the first century Caius Ennius Hispanus. Genaro Chic relates the name of the pottery to a brooklet, Riuus Saenus. III Enniorum Iuliorum stamps were found in Britain at London, Corbridge, Holt, Brecon, York, Brecongaer, Richborough, Shorden Brae, Silchester, StokeAssh, Wroxeter and Chester, and Hisp( ) Sae( ) at London, Caersws, York and Cirencester.
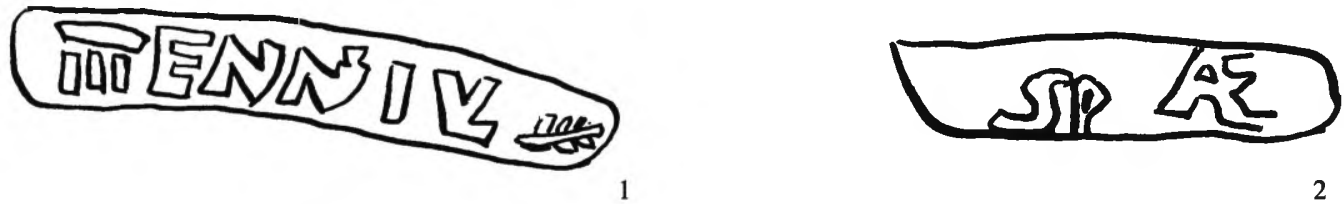

2

Pedro Paulo A. Funari *

\section{References}

\author{
CALLENDER, $M$. \\ (1965) Roman amphorae, with an index of stamps. \\ Oxford University Press, Oxford. \\ PONSICH, M. \\ (1979) Implantation rurale antique sur le Bas- \\ Guadalquivir II. De Boccard, Paris.
}

REMESAL, $\mathbf{J}$.

(1986) La annona militaris y la exportación del aceite bético a Germania. Universidad Complutense, Madrid. 